\title{
Determinants Of FDI Inflows In High Income Countries: An Intertemporal And Cross Sectional Analysis Since 1990
}

Behrooz Shahmoradi, Mysore University, India

Navitha Thimmaiah, Mysore University, India

S. Indumati, Davangere University, India

\begin{abstract}
The marked rise of FDI flows to high-income countries since the early 1990s has prompted substantial empirical research into the important determinants of FDI. This paper also has attempted to identify important determinants of FDI inflow for the selected high-income countries (23 countries) since 1990. Based on the related review of literature, six variables (Outflow, GDP, BOP, Export, Import and Labor) have been selected. Employing adding-up/multiple regression models, significant determinants were identified.
\end{abstract}

Keywords: High Income Countries, Determinant of FDI, Inflow, Outflow and Adding-up Model

\section{INTRODUCTION}

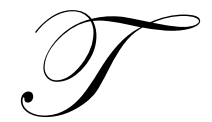

he marked rise of FDI flows to High Income (HI) countries since the early 1990s has prompted substantial empirical research into the underlying factors, for at least two reasons. First, FDI has become an important part of the domestic economy. Second, foreign investments played, and still play, a crucial role in the recipients' transition from centrally planned economies to market economies, providing substantial financial capital, technological know-how and managerial expertise. Yet the patterns of absolute and relative FDI inflows have been quite erratic with respect to developed countries.

Therefore, an in-depth analysis of the factors determining FDI inflows is needed not only to understand these aspects, but also to predict future patterns of FDI relating to HI countries and to provide policymakers with guidelines on how to improve FDI inflows.

The objectives of the current study are:

- $\quad$ To analyze the determinants of FDI inflows in high income countries

- $\quad$ To highlight the main determinants of FDI inflows over different years

The study is an attempt to evaluate FDI behavior in selected HI countries ${ }^{1}$ in relation to important determinants of FDI, which have been highlighted in previous studies.

To guide the analysis, the study starts with a summary of the major trends in inflow of foreign direct investments in selected high-income countries since 1990. A brief discussion on the main theories of FDI determinants precedes the analysis of the empirical literature on the same issue.

\footnotetext{
${ }^{1}$ Australia, Austria, Canada, Denmark, Finland, France, Germany, Hong Kong, Ireland, Italy, Japan, Korea, Mexico, Netherland, Norway, Portugal, Saudi Arabia, Singapore, Spain, Sweden, Switzerland, U.K, U.S.
} 


\section{THEORETICAL AND EMPIRICAL BACKGROUND}

Though there has been considerable theoretical work on foreign direct investment (see e.g. Hymer (1960); Caves (1982); Buckley and Casson (1976)), there is no agreed model providing the basis for empirical work. Rather, Dunning's (1974, 1980) OLI (Ownership, Locational and Internalization) paradigm has provided a taxonomic framework for most estimating equations. Dunning proposes that FDI can be explained by three categories of factors; ownership advantages $(\mathrm{O})$ for firms to operate overseas, such as intangible assets, locational advantages to investment in the host rather than the home country (L), and the benefits of internalization (I).

The literature indicates that the key locational factors determining FDI are country's market size, input costs - notably of natural resources and labor — and openness of an economy (see e.g. Singh and Jun (1995); Culem (1988)). Market size, typically measured by host country Gross Domestic Product (GDP) captures potential economies of large-scale production. In the transition context, survey evidence suggests that most firms invested in search of new market opportunities (Lankes and Venables (1996)), which can also be related to absolute market size.

Expected profitability will also be higher if inputs costs, most notably labor, energy and raw materials costs, are lower than in the donor economy. For most of the transition economies, the key resource is labor, which is regarded as having relatively high levels of skills and training (in comparison for example to regions with comparable per capita income levels in South East Asia or Latin America) and a strong scientific base (see EBRD (1999)). This aspect indicates the inclusion of labor in the present analysis of FDI inflows in HI countries.

It is also widely argued that FDI and openness of the economy will be positively related (see Caves (1996); Singh and Jun (1995)). This, in part, proxies the liberality of the trade regime in the country and, in part, the higher propensity for multinational firms to export and import. Therefore, the degree of openness of the country can be measured by its export as well as its import. While determinates of BOP can be the country's exports and imports of goods, we can then conclude that BOP can be correlated to FDI too.

Higher FDI outflow may also enhance the capability of the home country in undertaking FDI inflow (Banga, 2007) with a lag, by enhancing the flow of non-debt private capital and technological and managerial skill, creating domestic employment through backward linkage effects, and by building up the foreign exchange reserves of the country. Thus, FDI inflows and outflows could be complementary. On the other hand, it may be a plausible theoretical proposition to argue that entry of foreign firms represented by FDI inflows increases competition in the domestic market, which in turn forces domestic firms to seek additional markets through exporting and FDI outflow. It is therefore topical to get an insight into the effect of FDI outflows into corresponding inflows.

Recent empirical works have tried to establish the determination of FDI inflows by considering economic growth, export, import, labor productivity, or a combination of them. But in the literature review, relatively few published empirical works deal with determinant relations among more than two variables simultaneously in a group of countries ${ }^{2}$.

\section{METHODOLOGY}

Multiple regression methodology has been employed to identify significant variables in determining FDI inflows on HI countries. Data on FDI inflow, outflow, GDP, BOP, Export, Import and labor once every five years since 1990-2007 - have been considered. ${ }^{3}$

\footnotetext{
${ }^{2}$ Aharoni (1966); Kobrin (1979); Davidson (1980); Buckley and Mathew (1980); Root (1987); Young, Hamill, Wheeler, and Davies (1989); Sabi (1988); Fuat Erdal and Ekrem Tatoglu (2002); Anjum Aqeel and Mohammed Nishat (2005); emphasized that GDP, export and import are most important determinant of FDI. Liu et al. (2000); Vahter (2004); Girma (2005) ;Thiam (2007) studied on labor. Meanwhile Fry (1993); Jansen, K. (1995); Woodward (2001).Arslan Razmi (2007) on BOP.

${ }^{3}$ Inflow: US Dollars at current prices in millions, Source UNCTAD World Investment Report Database 2008. Outflow: US Dollars at current prices in millions, Source: UNCTAD World Investment Report Database 2008. GDP: GDP per capita in U.S. dollars, Source: International Monetary Fund, World Economic Outlook Database, October 2008. BOP: Current account balance, Source: International Monetary Fund, World Economic Outlook Database, October 2008. Labor: Total labor force, Absolute Value in thousands, Source: International Monetary Fund, World Economic Outlook Database, October 2008.
} 
To identify the impact of each variable on FDI inflows, Adding $U p M_{\text {odel }}^{4}$ was employed. Data on FDI inflows was first regressed on outflow. In the next stage, GDP was added to outflow. Other determinants were added in subsequent stages. Hence, with six explanatory variables, we ended with six models for each year (see Table 1).

Table 1: Adding up Model of Determinant Variables of FDI Inflow in 1990

\begin{tabular}{|l|l|l|l|l|l|l|l|l|l|}
\hline & Constant & Outflow & GDP & BOP & Export & Import & Labour & $\mathbf{R}^{\mathbf{2}}$ & $\check{\mathbf{R}}^{\mathbf{2}}$ \\
\hline Coefficient & 5219.990 & 0.653085 & & & & & & 0.310507 & 0.277674 \\
\hline T & 0.498409 & 3.075251 & & & & & & & \\
\hline Sig & 0.6234 & 0.0057 & & & & & & & \\
\hline Coefficient & 10973.88 & 0.682189 & -0.204174 & & & & & 0.314337 & 0.245771 \\
\hline T & 0.541392 & 2.917534 & -0.334253 & & & & & & \\
\hline Sig & 0.5942 & 0.0085 & 0.7417 & & & & & & \\
\hline Coefficient & 12097.92 & 0.800515 & -0.409312 & -140.6493 & & & & 0.573414 & 0.506058 \\
\hline T & 0.737375 & 4.160616 & -0.821915 & -3.396936 & & & & & \\
\hline Sig & 0.4699 & 0.0005 & 0.4213 & 0.0030 & & & & & \\
\hline Coefficient & 7695.856 & 0.738312 & -0.363076 & -129.4816 & 0.017100 & & & 0.578942 & 0.485374 \\
\hline T & 0.404234 & 3.149855 & -0.702085 & -2.691773 & 0.486138 & & & & \\
\hline Sig & 0.6908 & 0.0055 & 0.4916 & 0.0149 & 0.6327 & & & & \\
\hline Coefficient & 9845.175 & 0.633297 & -0.406176 & 219.7704 & -0.296727 & 0.313495 & & 0.624790 & 0.514434 \\
\hline T & 0.530657 & 2.649157 & -0.807161 & 0.890531 & -1.346267 & 1.441271 & & & \\
\hline Sig & 0.6025 & 0.0169 & 0.4307 & 0.3856 & 0.1959 & 0.1677 & & & \\
\hline Coefficient & 12388.71 & 0.403288 & -0.492897 & 429.1030 & -0.490830 & 0.601896 & -1.070160 & 0.669006 & 0.544883 \\
\hline T & 0.686517 & 1.441085 & -1.004313 & 1.540529 & -1.953032 & 2.085952 & -1.461976 & & \\
\hline Sig & 0.5022 & 0.1688 & 0.3302 & 0.1430 & 0.0685 & 0.0534 & 0.1631 & & \\
\hline
\end{tabular}

FDI inflows $=\beta_{0}+\beta_{1}$ Outflow $+u_{1}$

FDI inflows $=\beta_{0}+\beta_{1}$ Outflow $+\beta_{2} G D P+u_{2}$

FDI inflows $=\beta_{0}+\beta_{1}$ Outflow $+\beta_{2} G D P+\beta_{3} B O P+u_{3}$

FDI inflows $=\beta_{0}+\beta_{1}$ Outflow $+\beta_{2} G D P+\beta_{3} B O P+\beta_{4}$ Export $+u_{4}$

FDI inflows $=\beta_{0}+\beta_{1}$ Outflow $+\beta_{2} G D P+\beta_{3} B O P+\beta_{4}$ Export $+\beta_{5}$ Import $+u_{5}$

FDI inflows $=\beta_{0}+\beta_{1}$ Outflow $+\beta_{2}$ GDP $+\beta_{3} B O P+\beta_{4}$ Export $+\beta_{5}$ Import $+\beta_{5}$ Labor $+u_{6}$

Likely because of interrelatedness of certain explanatory variables like BOP, Import and Export, and observing the results of adding up model, the data were checked for multi-collinearity problems at each stage with the help of correlation analysis, partial correlations, Variance Inflation Factor (V.I.F), Conditional Index (C.I) and Tolerance (TOL). It was observed that multi-collinearity problems existed in the models where Import was included as an explanatory variable. Therefore, Import was excluded from the analysis. The variables were identified as important determinants in explaining FDI inflows after checking for multi-collinearity problems, significance of the parameters, and $\breve{\mathrm{R}}^{2}$ values. Subsequently, the findings for all years considered were discussed as follows.

In 1990, BOP and Outflow were the two important determinants of FDI inflows with $\breve{\mathrm{R}}^{2}$ value of 0.843 . In the multiple regression model where all the variables were considered, V.I.F indicated that there were multicollinearity problems with export and import. Regarding significance of variables, GDP was insignificant and Labor, though significant, had a negative sign. Hence, at the next stage, FDI inflows was regressed on BOP, Outflow and Labor. In this model, Labor turned out to be insignificant whereas V.I.F and C.I were good enough for BOP, Outflow and Labor. So, as indicated in Table 2, regression model, with BOP and Outflow as explanatory variables, was considered, which yielded $\breve{\mathrm{R}}^{2}$ value of 0.843 and significant $t$ values of -9.582 and 6.043 without problem sof multi-collinearity and good TOL, VIF and CI statistics.

FDI inflows $1990=\beta_{0}+\beta_{1} B O P+\beta_{2}$ outflow $+u_{i}$

FDI inflows ${ }_{1990}=1635.225-375.267$ BOP +0.433 outflow $+u_{i}$

${ }^{4}$ A linear regression model may be built up by adding new independent variable to an existing model. 
Table 2: Coefficient of Outflow of FDI and BOP for 1990

\begin{tabular}{|c|c|c|c|c|c|c|c|c|}
\hline \multicolumn{9}{|c|}{ Coefficients(a) } \\
\hline \multirow{2}{*}{\multicolumn{2}{|c|}{ Model }} & \multicolumn{2}{|c|}{ Unstandardized Coefficients } & \multirow{2}{*}{$\begin{array}{c}\text { Standardized Coefficients } \\
\text { Beta }\end{array}$} & \multirow[t]{2}{*}{$\mathbf{t}$} & \multirow[t]{2}{*}{ Sig. } & \multicolumn{2}{|c|}{ Collinearity Statistics } \\
\hline & & $\mathbf{B}$ & Std. Error & & & & Tolerance & VIF \\
\hline \multirow[t]{3}{*}{1} & (Constant) & 1635.225 & 1182.356 & & 1.383 & .182 & & \\
\hline & OUTFLOW & .433 & .072 & .513 & 6.043 & .000 & .994 & 1.006 \\
\hline & BOP & -375.267 & 39.165 & -.813 & -9.582 & .000 & .994 & 1.006 \\
\hline
\end{tabular}

In 1995, Outflow and BOP explained variations in FDI inflows to a greater extent. In the adding-up model, the highest $\breve{\mathrm{R}}^{2}$ value was 0.818 when only Labor was absent as an explanatory variable; but the model had the problem of multi-collinearity, as indicated by collinearity statistics. GDP, though not collinear with other variables, was insignificant whereas Outflow, Export and Imports were highly collinear. Hence, the regression with BOP and Outflow ${ }^{5}$ was considered, which yielded $\breve{\mathrm{R}}^{2}$ value of 0.781 and absence of multi-collinearity problems.

FDI inflows ig95 $_{103}=3638.582-107.711 \mathrm{BOP}+0.413$ outflow $+u_{i}$

In the year 2000, the regression model, with all explanatory variables, resulted in a $\check{\mathrm{R}}^{2}$ value of 0.946 , but there were severe multi-collinearity problems as per V.I.F with all variables, except for GDP and Outflow. In the group of collinear variables, C.I indicated favorable results toward BOP and Export, so FDI Inflow was regressed, considering these four variables. With a $\check{\mathrm{R}}^{2}$ value of 0.870 and absence of multi collinearity problems, GDP turned out to be insignificant; so a model with only Outflow, BOP and Export, as regressors, was run, which resulted in a $\breve{\mathrm{R}}^{2}$ value of 0.814 , significance of all variables, and obviously the absence of multi-collinearity problems.

FDI inflows $2000=-1042.765-390.027$ BOP +.185 Export +0.166 Outflow $+u_{i}$

For the year 2005, 0.545 was the highest $\check{\mathrm{R}}^{2}$ value obtained, wherein all regressors were included. As per V.I.F and TOI statistics, only Outflow and GDP were free of multi-collinearity problems, whereas C.I was all right for all variables, except Labor. Coefficient of GDP had a negative sign and was also insignificant with a t value of 1.004. Hence, a regression model with Outflow and $\mathrm{BOP}^{6}$ was run. The model had a $\breve{\mathrm{R}}^{2}$ value of 0.514 , variables were significant, and there were no multi-collinearity problems.

FDI inflows 2005 $=699.61+0.74$ Outflow $-136.52 \mathrm{BOP}+u_{i}$

In the year 2007, the simple regression model, with only variable Outflow, yielded the highest $\check{\mathrm{R}}^{2}$ value of 0.779 per the results of the adding-up model. Even when all the variables were included, only Outflow was significant and $\breve{\mathrm{R}}^{2}$ value was 0.774 . GDP and Labor coefficients had a negative sign, which would theoretically be inconsistent. Among three other highly collinear variables, BOP was selected, as per the criteria explained earlier, and FDI was regressed on Outflow and BOP, which resulted in a $\check{\mathrm{R}}^{2}$ value of 0.788 in the significance of both Outflow and BOP with t-values of 6.77 and -1.393 , respectively, and the absence of multi-collinearity problems.

FDI inflows $s_{2007}=12943.16+0.596$ Outflow $-60.45 \mathrm{BOP}+u_{i}$

\section{CONCLUSION}

As mentioned earlier, most studies offer various determinants of FDI inflows. The present study demonstrated that all determinants do not equally appeal FDI inflows in all years considered. To be more specific, the study determined that BOP and Outflow turned out to be the two significant explanatory variables in all years, but the parameter of BOP was negative, indicating inverse relationship between FDI inflows and BOP. We can say that Outflow is emerging to be a major component in determining FDI inflows, especially in High Income countries.

${ }^{5}$ Outflow was considered among the collinear variables as it had lowest V.I.F.

${ }^{6}$ Among BOP, Export and Import, BOP was selected as it had lowest V.I.F 
Furthermore, Export was significant only in the year 2000. Another important finding is the insignificance of GDP in explaining FDI inflows, while many empirical studies have shown significant relationship between FDI inflows and GDP of an economy. The present study has a paradoxical finding that GDP has an insignificant relationship with FDI inflows. This may be due to consideration of cross-sectional data. Hence, the relationship between GDP and FDI inflows in HI countries can be further analyzed by considering time series data.

This analysis can serve as both a guide for a better comprehension of FDI inflows into the region, as well as a starting point for future research areas.

\section{AUTHOR INFORMATION}

Behrooz Shahmoradi, at present pursuing Ph.D at University of Mysore. The title of his thesis is "emerging issues in the flows of FDI between developed and developing countries since 1990". He has Published two papers entitled "Bivariate causality between FDI inflows and economic growth in India since 1990" and "Regional and Sectoral Disparities in Inflow of FDI in India-An Empirical Analysis" in the book entitled "Pervasive computing for Business: Trends and Applications" by IGI publishers, USA, 2009.

Dr. Navitha Thimmaiah, currently she is teaching as a lecturer at University of Mysore, India. She has completed her Ph.D in 2006. Some of her publications are: Article on "Special Economic Zones" in Administrative Training Institute's monthly news letter, Book titled "World Bank Assistance and Economic Development of Karnataka" under publication and Book titled "A Primer on Economics" published by Administrative Training Institute.

Prof. Indumathi. S. At present she is the Vice-chancellor of Davangare University, Karnataka and also Professor at Department of Studies in Economics and cooperation, Mysore University since 1994 with more than 25 years experience of teaching. Papers taught by her are International Economics, development economics, research methodology and etc.

\section{REFERENCES}

1. Aharoni, Yair. (1966), The Foreign Investment Decision Process, Graduate School of Business Administration. Boston, Mass: Harvard University Press.

2. Anjum Aqeel \& Mohammed Nishat (2005), "The determinants of foreign direct investment in Pakistan" Submitted for the 20 Annual PSDE Conferences to be held on 10-12 January 2005, Islamabad.

3. Arslan Razmi. (2009), Does pleasing export-oriented foreign investors help your balance of payments? A general equilibrium analysis, Oxford economic paper 61, Oxford, pp. 128-149.

4. Banga R. (2007), Explaining Asian outward FDI, ARTNeT Consultative Meeting on Trade and Investment Policy Coordination, 16-17 July, Bangkok.

5. Buckley, P. J. \& Mathew, A. M. (1980), "Dimensions of Market Entry Behavior of Recent U. K. First Time Direct Investors in Australia" Management International Review, 20 (2), pp. 5-51.

6. Buckley, P.J. \& Casson, M. (1976), The Future of the Multinational Enterprise, Macmillan, London.

7. Caves. (1996), Multinational Enterprise and Economic Analysis ( $2^{\text {nd }}$ Edition), Cambridge University Press, Cambridge and New York.

8. Caves, R.E. (1982), Multinational Enterprise and Economic Analysis, Cambridge University Press, Cambridge and New York.

9. Culem, C.G. (1988), "The Locational Determinants of Direct Investment Among Industrialized Countries" European Economic Review, Vol.32, pp. 885-904.

10. Davidson, W. H. (1980), "The Location of Foreign Direct Investment Activity: Country Characteristics and Experience Effects" Journal of International Business Studies, 11 (2), pp. 9-22.

11. Dunning, J.H. (1974), Economic Analysis and the Multinational Enterprise, Allen and Unwin, London.

12. Dunning, J.H. (1980), "The Location of Foreign Direct Investment Activity, Country Characteristics and Experience Effects" Journal of International Business Studies, pp. 9-22.

13. EBRD. (1999), Transition Report 1999, European Bank for Reconstruction and Development, London.

14. Erdal, F. \& Tatoglu, E. (2002), "Locational determinants of foreign direct investment in an emerging market economy: evidence from Turkey” Multinational Business Review, Vol. 10 No.1, pp. 21-7. 
15. Fry, M. (1993), "Foreign direct investment in a macroeconomic framework: finance, efficiency, incentives, and distortions" Working Paper 1141, World Bank, Washington, DC.

16. Girma, S. (2005), "Safeguarding Jobs? Acquisition FDI and Employment Dynamics in U.K. Manufacturing" Review of World Economics 141: pp. 165-178.

17. Hymer, S. (1960), The International Operations of National Firms: A Study of Foreign Direct Investment, MIT Press, Cambridge, Mass. (published in 1976)

18. Jansen, K. (1995), The macroeconomic effects of direct foreign investment: the case of Thailand, World Development, 23, pp. 193-210.

19. Kobrin, S. J. (1979), "Political Risk: A Review and Reconsideration" Journal of International Business Studies, 10 (Spring/Summer), pp. 67-80.

20. Lankes, H.P. \& Venables, A.J. (1996), "Foreign Direct Investment in Economic Transition: The Changing Pattern of Investments" Economics of Transition, Vol.4, pp. 331-347.

21. Liu, Xiaming; Siler, Pamela; Wang, Chengqi \& Wei, Yingqi. (2000a), "Productivity Spillovers from Foreign Direct Investment: Evidence from UK Industry Level Panel Data" Journal of International Business Studies31 (3), pp. 407-425.

22. Root, F. R. (1987), Entry Strategies for International Markets, Lexington, Mass.: Lexington Books.

23. Sabi, M. (1988), "An Application of the Theory of Foreign Direct Investment to Multinational Banking in LDCs" Journal of International Business Studies, 19 (4), pp. 433-448.

24. Singh, H. \& Jun, K.W. (1995), "Some New Evidence on Determinants of Foreign Direct Investment in Developing Countries" Policy Research Working Paper No.1531, The World Bank

25. Thiam, Hee Ng. (2007), "Foreign Direct Investment and Productivity: Evidence from the East Asian Economies" UNIDO, Staff Working Paper,

26. Vahter, Priit. (2004), The Effect of Foreign Direct Investment on Labour Productivity: Evidence from Estonia and Slovenia. Tartu: Tartu University Press,

27. Woodward, D. (2001), The Next Crisis? Direct and Equity Investment in Developing Countries. Palgrave, New York, USA.

28. Young, S., Hamill, J., Wheeler, C. \& Davies, J. R. (1989), International Market Entry and Development, Harvester Wheat sheaf: Prentice-Hall.

29. UNCTAD World Investment Report Database 2008.

30. International Monetary Fund, World Economic Outlook Database, October 2008. 